\title{
A STUDY OF URBAN MORPHOLOGY OF JAPANESE COLONIAL TOWNS IN NAN'YO GUNTO
}

\author{
Part 2 Koror in Palau \\ 南洋群島における日本植民都市の都市構造に関する研究 \\ (その 2) パラオ諸島コロール \\ Keiko ONO*, John P. LEA** and Tetsuya ANDO*** \\ 小野啓子, ジョン $P$ リー, 安藤徹哉
}

\begin{abstract}
Koror, capital of the Republic of Palau, was formerly administrative centre of Japanese Micronesia (Nan'yo Gunto) in the 30 years before World War Two. Opinions about the town offered by contemporary observers ranged from ones of admiration for its modernity to describing it as merely a low status outpost. This paper draws a distinction between the planned administration and government housing precinct in West Koror and the informal development of East Koror, as well as that between the mainland Japanese governing elite, the Okinawan migrants and the indigenous Palauan residents. It suggests that Koror's urban morphology in colonial times reflected its temporary status as a staging post on the path towards southern advancement (nanshin).
\end{abstract}

Keywords: Colonial towns, Japanese Micronesia, Nan'yo, Palau, urban morphology.

植民都市、日本統治下ミク.ロネシア、南洋、パラオ、都市構造

\section{INTRODUCTION}

.. the buildings, even in the dark, look modern and handsome, appro-

priate to the capital of the Japanese South Seas (Umesao, 1944: 405).

Contemporary accounts about Koror, capital of the Japan's empire in the South Seas in the first half of the twentieth century, express surprise at the existence of a modern town in such a remote location. Tadao Umesao (1944) and the American journalist Willard Price (1936), for example, describe it as being well-designed and equipped. Located in the small Palau island group, Koror was administrative centre of Japanese Micronesia from 1922 to 1945 (Nan'yo Gunto) (Figure 1). This western Pacific region was formerly controlled by Germany but mandated to Japan by the League of Nations after World War One. Koror's urban population had increased from 1,426 in 1920 to 14,218 by the end of the 1930s (Japanese Population Census 1920; Nan'yo Cho.1941a). This was nearly as large as that of Garapan, the other major urban centre in Japanese Micronesia (see Part 1: Ono, Lea and Ando 2002).

Little now is left of the Japanese era with its avenues, administration buildings and government housing areas, all of which symbolised modern development in the tropics. Thirteen thousand Japanese residents were repatriated at war's end and much of the town bulldozed by the American victors in an attempt to remove all traces of the enemy occupation. Two scholars in particular have looked at colonial Koror in some detail. Ehrlich's (1984) history of the town covers the early foreign contact period until the Japanese era, though does not consider the circumstances of Japanese residents who made up 93 per cent of the town's population by 1939 (Nan'yo Cho 1941a). Additionally, a major work by Peattie (1988) based on the contemporary literature, examines the whole of Japanese Micronesia including the life and times of colonial Koror. But information on the built environment and how it accomodated different population groups has been limited.

This paper focuses on the urban morphology of Koror, how it evolved and functioned as a built environment and how residents experienced living in the town. It was thus necessary to speak both to Japanese informants now living in Okinawa, as well as islander residents in Palau. ${ }^{1}$ The Okinawans were the largest migrant group, comprising 53 per cent of the Japanese population of Palau in 1939 (Nan'yo Cho 1941a). They were described as an 'underclass' in the Japanese community by Peattie (1988: 221), and little is known about their experience of urban life

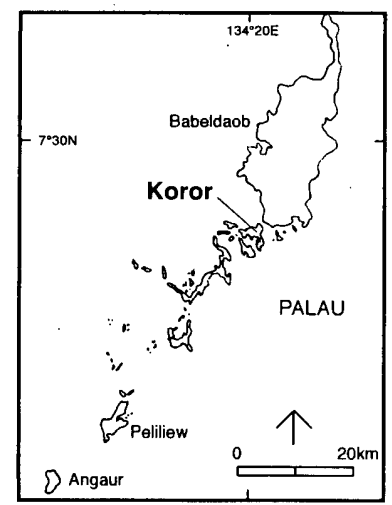

Figure 1 Main Islands of Palau Group
* Doctoral Student, Dept. of Architecture, Planning and Allied Arts, Faculty of Architecture, University of Sydney, M. Eng., M. Arch.

** Assoc. Prof., Dept. of Architecture, Planning and Allied Arts, Faculty of Architecture, University of Sydney, Ph. D., DScArch.

*** Assoc. Prof., Dept. of Civil Engineering and Architecture, Faculty of Engineering University of the Ryukyus, Dr. Eng.
シドニー大学建築学部博士課程

大学院生・修士 (工学, 建築学)

シドニ一大学建築学部 助教授・博拉 (学術, 科学)

琉球大学工学部環境建設工学科 助教授 ·博士 (工学) 


\section{SOCIALAND ECONOMIC FEATURES OF $\mathbb{K O R O R}$}

Unlike the Northern Marianas, the Palau islands were little influenced by colonialism prior to the nineteenth century. The central village of Koror was the most established among the few permanent settlements on Koror island. Some features of modernisation were introduced during the short German colonial period from 1899 to 1914 , when a government station was established in Madalai at the western end of Koror island, together with a new stone pier and dirt footpath across the island. But even so, the physical impact was minor as the number of German administrators was small. The German contribution to modern development was chiefly felt on Angaur island where a phosphate mine was established in 1909 (Yamamoto 1917; Ehrlich 1984)

\section{2-1 Establishing Koror}

The Japanese made use of what the Germans left behind and began their own extensive transformation of Koror in 1922 when the town became the administrative centre of Nan'yo Gunto. Because it was mandated and not a colonial territory, extra care was necessary not to unduly disturb the existing Palauan village of old Koror. Thus the administrative facilities were built on the western side of town where most of the important elements, such as the government buildings, social club, city park, hospital and post office were positioned along the main street. An economic boom starting in the mid-1930s swallowed up most of the original village and a pleasure district emerged close to the shore on the lower side. Shopping strips also developed eastward along the main street and as a result old Koror became almost invisible. In the town centre simple wooden buildings were replaced by permanent modern department stores and offices. Mango trees and palms planted along the main street provided shade and causeways connected Koror, Malakal and Arakabesang islands. 2-2 The Narrow Local Economy

Unlike the Northem Marianas, Palau depended on government services and did not possess anything equivalent in size or prosperity to the sugar industry (Figure 2). Only the phosphate mining on Angaur (and later on Peliliew) was at all comparable and at the beginning of the 1930s produced only one tenth of the exports by value of those from the sugar fields of Saipan (Nan'yo Cho 1937). Other economic activities around Koror included some trading and a bonito fishery. In the late 1930s, servicing the pearl-shell fishery based in southern waters brought the town an economic boom but this industry was far from stable and declined within a year or two (Maruyama 1940). The local economy was sustained however by the development in Palau of a naval base (Figure 3). In 1920 the Japanese population of Koror town (including those living on Malakal and Arakabesang islands) was only 454 but by the end of the 1930s had grown to 13,000 Japanese residents (Table 1). ${ }^{2}$

\section{2-3 The Koror Urban Community}

The character of the Japanese community in Koror reflected the broader colonial functions of Palau which was a base for over 40 per cent of Nan'yo Gunto government employees. ${ }^{3}$ It is estimated that on Koror island as a whole bureaucrats and their families made-up one third of the Japanese population in the mid-1930s and their presence was much more pronounced than in any other Micronesian towns. ${ }^{4}$ Although the ratio of Okinawans in the Japanese population of Palau was not as dominant as it was in the Northern Marianas where they comprised over 70 per cent, they were more concentrated in the urban area. The Palauans retained a presence in the town throughout the Japanese period but by the end of 1930s they comprised less than seven per cent of the town's population (Table 1).

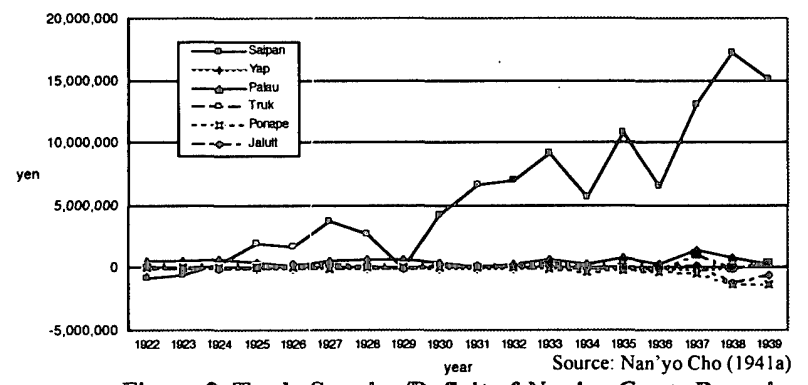

Figure 2 Trade Surplus/Deficit of Nan'yo Gunto Branch Governments, 1920-1939

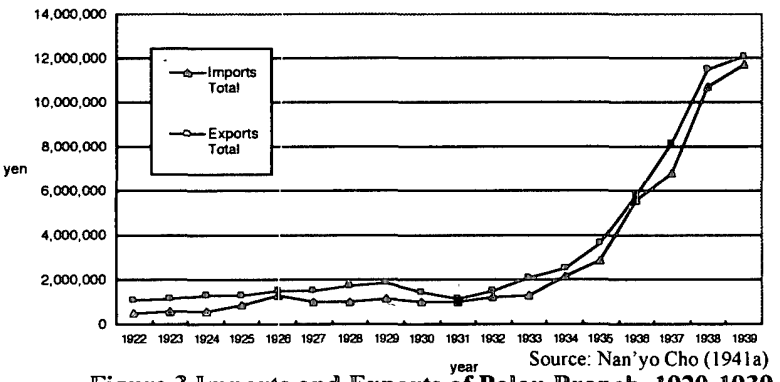

Figure 3 Imporís and Exports of Palau Branch, 1920-1939

Table $\mathbb{1}$ Population of Palau Branch and Koror Town, 1920-1939

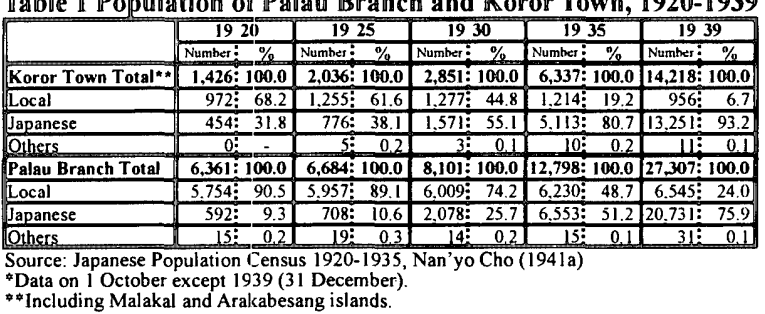

\section{URBAN MORPHOLOG Y OF $K$ KOROR}

... around Nan'yo Cho is a modern avenue lined with impressive buildings... but if one goes further into the suburbs, or steps into the side streets [of Koror], there is confusion and poverty suggesting we have strayed into a Chinatown. The shops are small and dirty... (Umesao 1944: 407).

This description highlights some of the contrasts in Koror. First, is the one between the western (mostly government area) and eastern parts (mostly commercial area) (Figure 4). In the western part (called West Koror in this paper) which was not occupied by Palauans, the newly mandated government provided modern streets and facilities. In the east, on the site of the old Koror village (called East Koror in this paper), there was no attempt to relocate the Palauan population nor make changes to the original land ownership. Developments here were of the informal kind with Japanese migrants building on leased land, creating a sprawling, high density urban area. ${ }^{5}$ Secondly, there was a contrast between the main street and the area behind it in East Koror where only the main street was widened, straightened and paved. ${ }^{6}$ Government tree planting was absent and continuous storefronts of smaller shops formed the streetscape for the main street. Behind it was the densely built-up old Koror village?

Many features of Koror can best be understood when compared with Garapan, the other major urban centre in Japanese Micronesia. The town of Garapan had a relatively homogeneous urban structure because the Spanish administration had completely removed and relocated the indigenous popu- 
lation. Succeeding colonial governments, including that of Japan, were able to impose an orderly grid pattern. Additionally, Garapan, as the commercial hub of Micronesia, was a place where developments were usually undertaken on an individual basis, resulting in a more fragmented land use pattern

\section{3-1 The Land Use Pattern of Koror}

A new land use map of Koror was compiled from earlier published sources and information provided by former residents. It indicates that urban land use can be categorised into at least seven distinctive zones (Figure 5). Three key components already noted by the authors in relation to Garapan which characterise Japanese colonial towns in the Pacific are also visible here (Ono, Lea and Ando 2002). They are: a modern precinct containing government and company housing; a Japanese commercial centre comprising hundreds of shops, both large and small; and a pleasure district serving the needs of Nan'yo Cho officials and the pearl diving crews.

The Government Precinct/Housing Area (A: Figure 5)

Government facilities were concentrated along the palm-lined main avenue in West Koror, creating a modern appearance befitting the regional capital (Figure 6). High ranking officials lived in quiet enclosure here at Yuhigaoka (sunset hill), behind the Nan'yo Cho headquarters, and those in the middle ranks in Asahigaoka (sunrise hill) behind the new Palau Branch government buildings. Housing was also provided here for some of the established companies, such as Nan'yo Boeki (NBK). Few islanders lived in this part of the town except for those left untouched in the small indigenous village at Ngermeched. Japanese

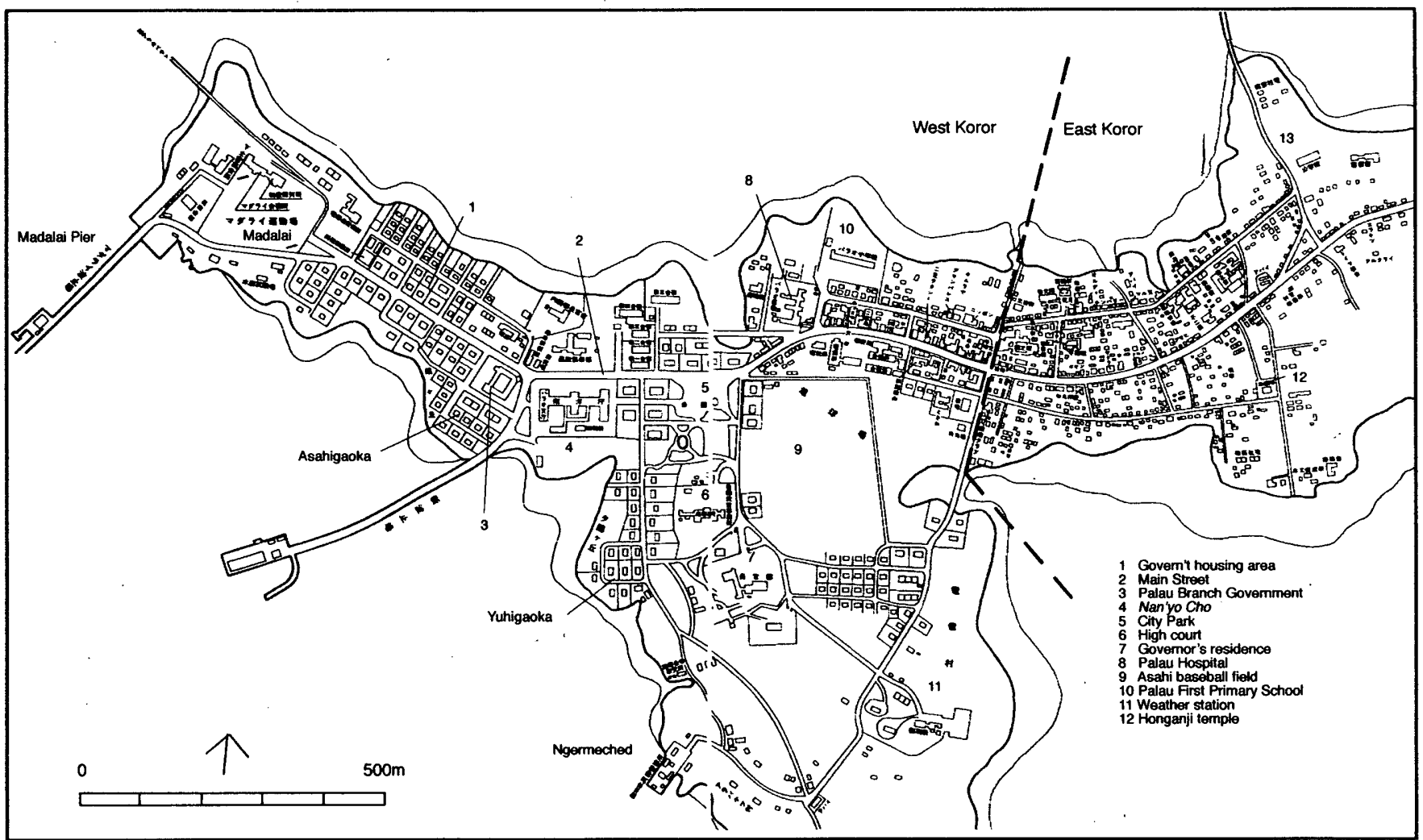

Figure 4 Koror in 1938. (Source: after Kosuge 1985: 22-23)

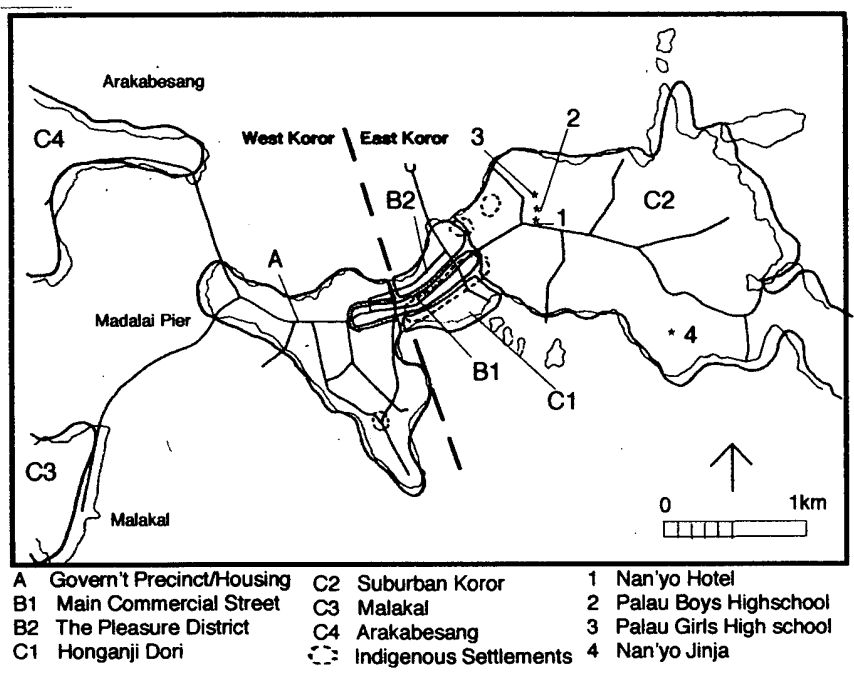

Figure 5 Land Use Pattern of Koror in the Late 1930s to the Early 1940s.

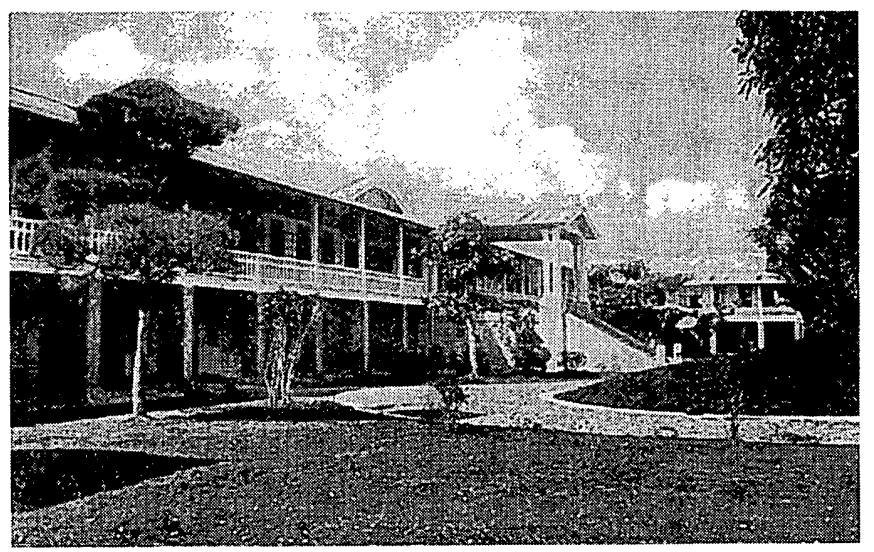

Figure 6 Nan'yo Cho in Koror in the 1930s. (Source: Futabaya gofukuten 1935) 
residents here were the governing elite mostly from the mainland.

\section{The Main Commercial Street (B1: Figure 5)}

The commercial strip developed along the main street. Most established businesses such as NBK, a modern two-storey concrete department store, and the Nakajima store were located on the West Koror side, closer to the government precinct (Figure 7). In East Koror strips of smaller shops continued, along with some abai (Palauan men's house) buildings and thatched houses. Families here lived mostly at the back of the shops.

\section{The Pleasure District (B2: Figure 5)}

By 1939, four inns, 13 ryotei (restaurants, mostly brothels), and 40 other cafe/bars and eating places were concentrated in the busy pleasure district of East Koror (Figure 8). Imports of beer to Palau, one of the most expensive drinks at this time, were almost two-and-a-half times greater than those to Saipan. In addition, the number of geisha women working in Palau was three times that found in Saipan, indicating customers were able to afford more on entertainment in Koror (Nan'yo Cho 1941a).

\section{Other Urban Areas (C1,C2 and C3: Figure 5)}

Many small houses and some shops stood along Honganji Temple street (C1). In the 1940s suburban Koror (C2) included some indigenous settlements, Japanese small holdings and several public buildings, like high schools. Kanpei Taisha Nan'yo Jinja, one of the few high ranking shinto shrines outside of mainland Japan, ${ }^{8}$ was also built here in 1940 and the ceremonial access road extended (Umesao 1944). Koror's tidy appearance was in part due to the fact that its most intrusive industries and installations were not located in the town but occupied sites on the neighbouring small islands of Malakal (C3) and Arakabesang (C4). The fishery on Malakal supported an urban community of 3,600 Japanese (Nan'yo Cho 1941 a), many of whom were Okinawans. The chief naval base was established on Arakabesang and also serviced a sea plane facility.

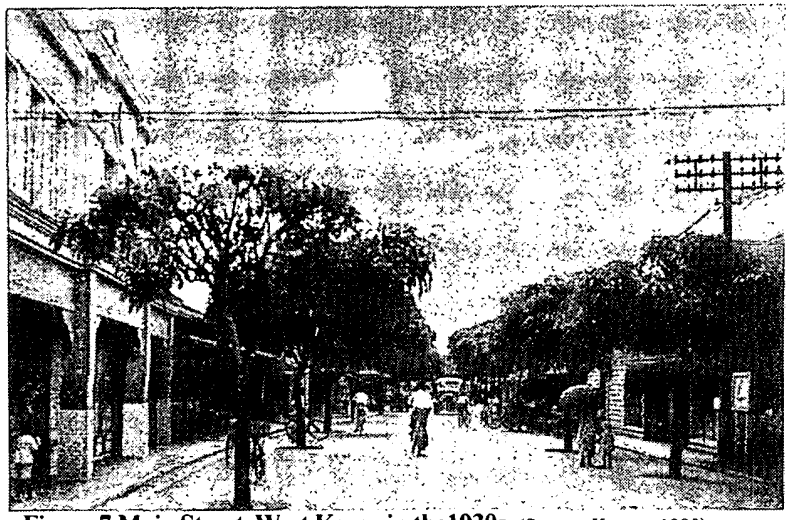

Figure 7 Main Street, West Koror in the1930s. (Source: Kosuge 1990)

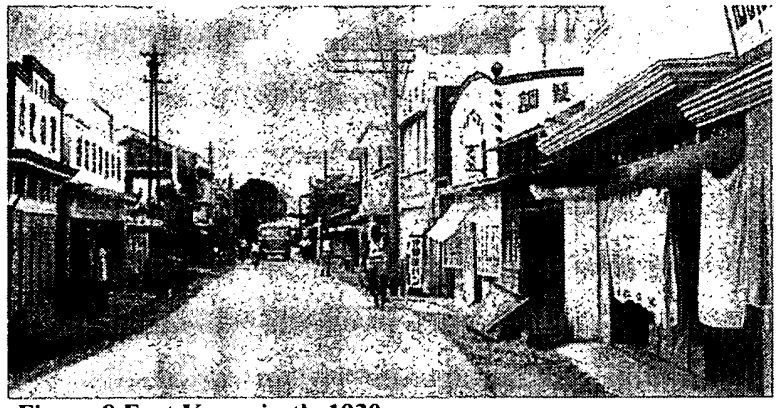

Figure 8 East Koror in the1930s. (Source: Kosuge 1990)

\section{LIVING IN KOROR}

The experience of living in colonial Koror can be distinguished according to three main groups in urban society at the height of Japanese settlement in the 1940s. These were: the ruling Japanese mainland elite; the migrant majority from Okinawa; and small numbers of progressively urbanised Palauans.

\section{4-1 Mainland Japanese: the ruling elite}

Life was easier for most officials in Koror than they were used to at home. They worked from eight to noon, spent long afternoons at the social club indulging at go, mahjong, billiards, table: tennis and archery. Tennis and baseball were played at the sports ground in Maclalai and later at the Asahi baseball field. After dark, many spent evenings at ryotei in the pleasure district where they were covered by monthly credit arrangements. It was said every business in Koror except the post office was willing to allow credit as an alternative to savings (Nonaka 1934), indicating the importance of the public sector in the urban economy of the capital. Most wives stayed at home looking after their children and did not need to go shopping, as groceries were delivered daily to the door by the Nakajima store (personal commnication, Okinawa, February 2001). The government houses were generally simple wooden buildings with two rooms, kitchen, bathroon and a hiroen (verandah) (Figures 9 and 10). The floor was raised to give better ventilation. Inside the house were tatami mats ${ }^{9}$ and there was little furniture except a low table and some rattan chairs which seem to have been popular among officials in Nan'yo Gunto for the use on their verandahs (Figure 11). The islanders' children when seen in the area, except for those from the small village of Ngermeched, were mostly renshusei (trainees also called boi) assigned by the school to work for a specific Japanese household on the premise that they would learn the لlapanese language and customs.

However, as novelist Tatsuzo Ishikawa noted, by Japanese standards all the government houses were small, 'like shacks', and 'the city had the strange atmosphere of a temporany place' (Ishikawa 1943: 64). ${ }^{10}$ The late Teruo Kosuge, a former NBK employee, described the town as 'a rustic outpost' (personal communication, Tokyo, November 1998). Upon arriving in Koror from Tokyo, Yoji Kurata, who worked for Nan'yo Cho, thought it was a tidy but 'petty town.' For him Koror was merely a 'transient stop' at the developing frontier of the South Seas (personal communication, Palau, December 2000).

\section{4-2 The Okinawans: a working class}

Okinawans in Koror may have occupied the lowest rung of the work force and had a basic life style but, unlike the conditions at home, none of them had problems finding food and money was always available (personal communications, Okinawa, February 2001). Because many of them were dispersed on Malakal and in East Koror, the Okinawan quarter in Koror was not as distinctive a place as found in Garapan.

In East Koror, on the lower side of the pleasure district near the water, there was a community of inshore fishermen from Kunigami on Okinawa Island. The men caught the fish and the women sold them in town. In the small businesses the Okinawan families, including children, worked very hard. Yoshi Yamashiro, for example, worked afer finishing sixth grade in primary school in a family vegetable shop in the mornings, a shaved ice parlor during the rest of the day, and at a restaurant at night, all of them ran from their house. Shintoku Taira, whose father was a sawyer, helped his 
mother after school to grow vegetables and raise pigs. In spite of this, he successfully passed the entrance examination for Palau Boys' High School and became a high school teacher in the post war years. Because he lived in suburban Koror where there were less Japanese he always played with Paluan children. However, in the town centre interaction with the Palauan children (who were separately schooled at the kogakko) was limited (personal communications, Okinawa, February 2001)

Because most Okinawans were not engaged in farming, the range of jobs they occupied in Koror was wider when compared to the situation in the Northern Marianas. At the high end were the successful fishermen who owned many boats, as well as the inn and restaurant owners, and government officials. Shigeko Sakugawa, who was born in Koror in 1932, and whose parents came from Motobu on Okinawa Island, ran the Fujiya Inn. The family business went so well that they also invested in a taxi company in Koror, bonito boats at Arakabesang, a ceramics factory in Babeldaob, and owned several rental houses. The family of seven lived at the back of the inn and had a Japanese maid. The children were able to enjoy milk and oven fresh bread bought in their neighbourhood every morning (personal communication, Okinawa, February 2001).

\section{4-3 The Palauans}

From kogakko to the Palau branch government building, the houses stood so close together that we could walk under their roofs without an umbrella (personal communication of a Palauan resident born in 1929, December 2000)

Interestingly, nearly every Palauan spoken to in December 2000 reminisced in a similar way about how one could walk along the main street without using an umbrella. However, when asked to confirm this, none of the former Japanese residents had similar recollections. It does seem to be an exaggeration; judging from historic photographs of Koror, although there were some roofed sections of storefronts on the main street. ${ }^{11}$

Roles played by the Palauans in town were minor and unskilled, like working in the local police force (the junkei), and low level jobs in companies and at stores. The pay was lower for the islander work force. There were also some Palauan families, particularly in East Koror, who leased land to the Japanese. However, although nearly one thousand Palauans lived in East Koror, many Japanese residents hardly noticed they lived close by. Others were engaged in small scale taro and bread fruit subsistance farming in the suburbs. Palauan children who worked as a boi (boy) were paid small amounts when they reached the age of ten (third year in kogakko). But being a boi-san was not a pleasant experience for all of them (personal communications, Palau, December 2000).

For the mainland Japanese, the town of Koror was impressively modern and tidy for such a remote outpost and, more importantly, was also able to stir the romanticism and frontier spirit of southern advancement (nanshin) in many, from intellectuals to the young. ${ }^{12}$ For most Okinawans the town symbolised a modern place where they were free to pursue new economic opportunities. But the Palauans, although able to maintain a physical presence in the town, were not really a true part of it. Their urban experience was rather superficial and fragmented. After much of the town was physically destroyed only images of a thriving place seem to have remained to become the subject of stories.

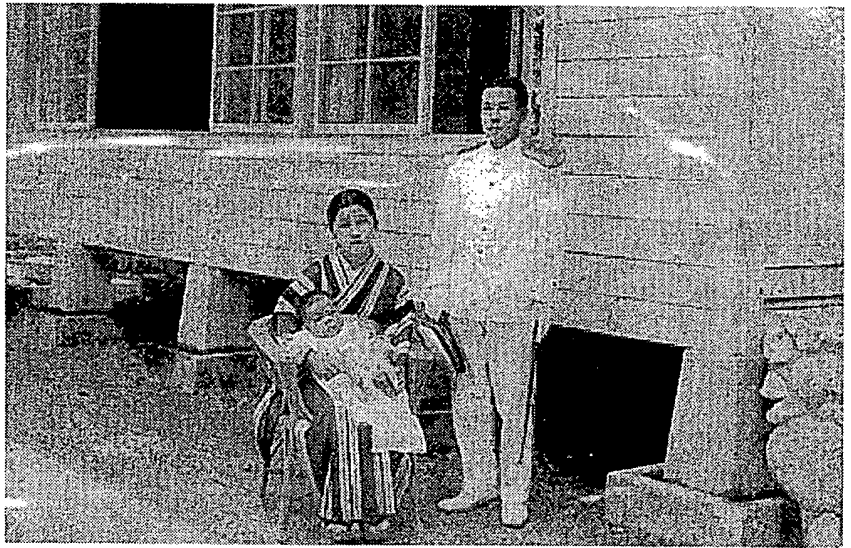

Figure 9 Nan'yo Cho Medical Doctor's Family at Their Government House in Palau in the 1930s. (Source: Private Collection)
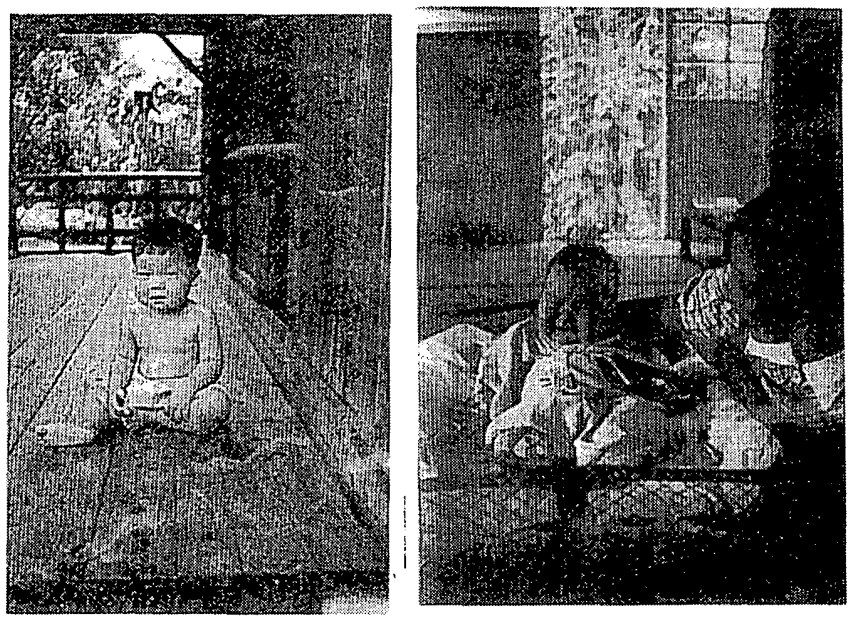

Figure 10 Hiroen (verandah) of Figure 11 Interior of the Same House. the Same House. (Source: Private Col- (Source: Private Collection) lection)

\section{CONCLUSION}

The findings of this study suggest that Koror's urban morphology was characterised by several key features:

First, are distinctive components that also characterise the Japanese colonial towns of the Northern Marianas. These are: the presence of an exclusive precinct symbolising modemity and advancement containing government buildings and housing; a commercial area comprising numerous shops that provided a wide range of urban services to cater for the daily needs of Japanese residents; and a pleasure district which played a crucial role in Japanese social and economic life.

Second, in Koror, these three components were settled in different ways from each other determined by the existing indigenous village of old Koror. The government precinct was planned and constructed at a separate location from old Koror village and occupied almost exclusively by the Japanese elite. The commercial area was built in old Koror village and was racially mixed. The Japanese greatly outnumbered the local population in this area.The pleasure district emerged in an uninhabited location behind the commercial area. Few Palauans lived in the pleasure district and it was mainly occupied by Japanese whose social and economic status varied from fishermen to wealthy inn owners.

Third, although Koror shared the basic characteristics of other Japanese colonial towns in the Pacific, one particular physical feature stood out. This was due to the effects of a small and narrow island resulting in an 
extremely linear urban structure. A tidy and attractive appearance for the capital of Japan's South Seas was effectively created with modernised facades for the public buildings, numerous shops beautified by avenues of trees planted along the single main access road from the port in Madalai at the western end to the town centre. Furthermore, Nan'yo Jinja was built in the 1940s on the eastern outskirts, granting a symbolic and ceremonial meaning to the main street whilst strengthening Koror's linear nature.

What exists in this town is only cheapness, like the feeling of basue

[on the margin] of a colonial territory, decadent, and oddly osten-

tatious (Nakajima 1942: 248)

As novelist Atsushi Nakajima (1942) ${ }^{13}$ intuitively pointed out, Koror's urban structure was as shallow and lacking in substance as its economy. Several strong contrasts existed within the town, such as those between the formal development in West Koror and informal developments in East Koror, and between the main street and densely settled areas behind it in East Koror. The immediate change between modernity seen on the street frontage and the vigorous confusion behind formed a set of complex images confronting visitors and residents alike, depending on what they wished to see and what their roles might be. Koror performed as a theatrical setting in which various resident groups participated in the consolidation of Japanese plans for the southern advancement of the empire. Although it may not have contained the grand buildings of European colonialism, the town fulfilled its primary function as a staging post from where future moves to the south could take place. When the show was over and the billboard veneer removed by the Americans at war's end, little was left behind besides memories. Today, Koror is remembered in ways closely reflecting the differences in the urban experiences of those who lived there and what it meant to each of them.

\section{ACKNOWLEDGEMENT}

The authors would like to thank the following individuals and organisations who assisted this research. Nan'yo Gunto Kikansha-kai and Okinawa Paraokai in Okinawa; Nan'yo Gunto Kyokai and Ms. Yumiko Imaizumi in Tokyo; Belau National Museum, Division of Cultural Affairs, Bureau of Lands and Surveys, Mr. Wilhelm Rengiil, Dr. Minoru Ueki, Mr. Yoji Kurata and Mr. Yoshitaka Ota in Palau; Dr. Dirk Ballendorf in Guam; and Dr. Jordan Sand in Washington D.C.

\section{ENDNOTES}

1 The authors met several former residents of Koror in Palau and Okinawa in 20002001, and attended meetings of the Nan'yo Gunto Kikansha-kai (association of repatriates from Japanese Micronesia). As numbers of possible informants with personal experience of colonial Koror grows less by the year, it was particularly important to check some of the written accounts with those who still remember what it was like to be a part of $\mathrm{Nan}^{\prime} y o$.

2 The total Japanese population of the Palau group in 1940 was 23,767 , while the Islander population was some 6,587 (Nan'yo Cho $194 \mathrm{lb}$ ). The Palauan population was mostly concentrated on Babeldaob island.

3 Calculated by the number of 'officials and freelancers' in 1939, in the Nan'yo Cho statistics (Nan'yo Cho 1941a)

4 Estimated by district populations recorded in the Japanese Population Census of 1935 5 Japanese nationals were not allowed to own land in Japanese Micronesia.

6 One $\mathrm{Abai}$ building was relocated to allow straightening of the main street. However, Ehrlich (1984) noted that the Japanese respected traditional village spaces even during the most intensive period of urbanisation.

7 These are confirmed in the US Navy aerial photography of March 1944, Collection of US National Archive, Maryland, USA. The photographs were found with the assistance of Jordan Sand, Georgetown University

8 Korea, Taiwan and Sakhalin had one each.

9 Use of tatami mats in Nan 'yo Gunto was limited in general. Mats spread on wooden floor seem to have been more common, particularly outside Koror (personal communications, Okinawa, February to March 2001)

10 The construction costs in Nan'yo Gunto were said to have been three times that in mainland Japan (Nonaka 19.34).

11 The same expression is found in the stories of elderly Ponapean man about preWorld War Two Kolonia (Pohnpei), who also exaggerated a two-storey high movie theater as being 'four-storeys' (Kosuge (eds) 1978: 117). 'Walking without umbrella' may be a widespread urban inyth in Micronesia about the great extent of urbanisation in the Japanese era. It is also assumed that the 'myth' was created in response to the devastating conditions founcl in some Micronesian town centres in the post war years. 12 For discussion of the Japanese southern advancement (nanshin), see Yano (1979). 13 Nakajima stayed in Koror while working on assignment for Nan'yo Cho to write Japanese text books for islander children.

\section{REFERENCES}

Ehrlich, Paul (1984) Koror: a Center of Power, Commerce and Colonial Administration, Micronesian Archaeological Survey Report No. 11. Saipan: Historic Preservation Office, Trust Territory of the Pacific Islands.

Futabaya Gofukuten (1935) Umi no seimeisen waga Nan 'yo no sugata (Nan 'yo Gunto shashin-cho) [Lifeline at teh Sea: the Images of our South Seas Islands (the South Seas Islands Photographs)], Koror: Futabaya gofukuten.

Imanishi, Kinji (eds) (1944) Ponape-to: seitaigakuteki kenkyu [Ponape Island: Ecological Research], Shoko Shoin.

Ishikawa, Tatsuze (1943) Akamushijima nisshi [Diary at Akamushi Island], Tokyo: Tokyo Yagumo Shoten.

Kosuge, Teruo (eds) (1978) Mukashi no Nan'yo Gunto shashin-cho [Photographs of the South Sea Islands Yesterday], Tokyo: Guamu Shinpo-sha

Kosuge, Teruo (eds) (1985) Nan 'yo Gunto mukashi ima [Micronesia Past and Present], Tokyo: Nan'yo Gunto Kyokai.

Kosuge, Teruo (eds) (1990) Fukkoku-ban: Sekido wo se ni shite [Reprinted: with the Equator at My Back], Tokyo: Nan'yo Gunto Kyokai

Maruyama, Yoshiji (1940), Nan'yo kiko [An Account of Travel to the South Seas], Tokyo: Koanihon-sha.

Nakajima, Atsushi (1942) Kansho: mikuronesiya junto-kisho [Reef: Document of Travelling around Micronesian Islands], republished in Nakajima Atsushi (1997) Tonan sensei; nanto-tan [Mr. Tonan: Stories of Southern Islands], Tokyo: Kodansha.

Nan'yo Cho (1937) Dai 5 kai Nan'yo cho tokei nenkan [The Fifth South Seas Bureau Statistics yearbook], Tokyo: Nan'yo Cho.

Nan'yo Cho (1941a) Dai 9 kai Nan'yo cho tokei nenkan [The Ninth South Seas Bureau Statistics Yearbook], Trokyo: Nan'yo Cho.

Nan'yo Cho (1941b) Nan'yo Gunto Yoran [Summary of the South Seas Islands], Tokyo: Nan'yo Cho

Nonaka, Fumio (1934) Sekido wo se ni shite [With the Equator at My Back], Tokyo: Chuo Joho-sha, republished in Kosuge Teruo (eds) (1990).

Ono, Keiko, John Lea and Tetsuya Ando (2002) A Study of Urban Morphology of Japanese Colonial Towns in Nan'yo Gunto Part 1: Garapan, Tinian and Chalan Kanoa, Journal of Architecture, Planning and Environmental Engineering, No. 556 (June 2002), pp. 336-339, Architectural Institute of Japan.

Peattie, Mark R (1988) Nan'yo: The Rise and Fall of the Japanese in Micronesia 1885-1945, Honolulu: University of Hawaii Press.

Price, Willard (1936) Pacific Adventure, New York: John Day.

Umesao, Tadao (1944) 'Kiko' [Travel Account], in Imanishi (eds) (1944), pp. 399-489.

Yamamoto, Miono (1917) Waga kokumin no kaigai hatten to Nan'yo shin senryoch [Our Nationals' Development Overseas and in the South Sea's New Territory], Kyoto: Kyoto-hogaku kai.

Yano, Toru (1979) Nihon no Nan'yo shikan [Japan's Historical View of the South Seas], Tokyo: Chuo Koronsha.

\section{和文概要}

日本統治下ミクロネシア (旧南洋群島) の首都であるパラオ・コロー ルは、1930年代後半に真珠採貝業や軍備等による経済的ブームによっ て大量の日本人が流入し、1940年代初めにはサイパンのカラパンと並 ぶ規模（1 万 5 千人弱）の都市となった。この論文は、文献、統計資 料、写真、地図、現地調査及び聞き取りに基づき、戦前のコロールの 都市構造及び都市居住の特質を明らかにしたものである。

植民都市としてのコロールは、北マリアナ諸島の諸都市と同様、計 画的につくられた官舎 (社宅) 街、日本人の日常生活を支える商店街、 多数の料亭がひしめき合う歡楽街の3つの主要素から構成されていた。 これらの要素は各々異なる社会・経済的特質を備え、また既存の集落 との空間的対応関係も異なっていた。さらに、コロール独自の特質は、 狭小な島という立地条件により非常にリニアな形状の都市が形成され たことである。その結果、並木のあるメインストリート沿いに南洋庁 等の近代建築が立ち並ぶ官舎街の西コロールと商店街である東コロー ル、東コロールにおけるメインストリート沿いの商業的都市景観と背 後の自然発生的な密集市街地という二つの強い対比的構図が居住者・ 訪問者に強い印象を与えることとなった。しかし、舞台装置のように 簡便につくられた都市景観は日本人の南洋の夢の終焉とともに簡単に 取り壊され、居住者には各自の都市経験に基づく断片的なイメージだ けが残されたのである。 